for åbenbaringsteologi.

Bogen er som antydet iscenesat som en række tematiske kampe, hvor de to - vel ikke mindst i deres selvopfattelse - teologiske giganter spilles ud i forhold til hinanden på en måde, så man nærmest har fornemmelsen af, at de lige nu og her kunne sidde overfor hinanden i et tryllebundet auditorium og udveksle vigtige filosofisk-teologiske pointer og gensidige giftigheder. Denne form, hvor Løgstrups og Sløks forfatterskaber og tænkning præsenteres og fortolkes i gensidig og ikke mindst ligeværdig dialog med hinanden gør bogen levende, men styrker samlet set også forståelsen af de to respektive forfatterskaber.

Politikens anmelder Lars Sandbeck begræder i sin anmeldelse af bogen, at Ole Morsing ikke harmoniserer "Løgstrups og Sløks tænkning", tager "parti for en af parterne" og " konsekvent undlader at diskutere, vurdere og kritisere", hvorved hele øvelsen bliver "udialektisk". Jeg må erklære mig helt uenig. Ved netop at fremstille Løgstrups og Sløks tænkning som langt hen af vejen inkommensurable størrelser får vi nemlig en sand dialektik - valgets dialektik - på banen. Løgstrups og Sløks tænkning er to forskellige bud på nogle af livets store spørgsmål. Begge bud er på egne betingelser gyldige, så vi er i bund og grund overladt til valget og afgørelsen, og dér efterlader Morsing os så på god dialektisk manér.

Det er ikke første gang, at Ole Morsing tager livtag med Løgstrups og Sløks indbyrdes forhold, men den lidt længere bogform, hvor der er plads til den føromtalte iscenesættelse virker som den helt rigtige platform. Bogen kan varmt anbefales som appetitvækker og indgangsvinkel til de to teologiske giganter og deres tænkning og forfatterskab, og som man har kunnet notere sig, så har interessen for bogen allerede været stor, hvilket kunne tyde på, at vi også har at gøre med en bog, der helt i både Løgstrups og Sløks ånd kunne risikere at få et liv uden for universitetsverdenens mure.

LARS ERSLEV ANDERSEN

\section{Illusioner om ikke-vold}

Mikkel Thorup: An Intellectual History of Terror. War, violence and the state, Routledge Critical Terrorism Studies, London, 2010, 282 sider.

Idehistoriken Mikkel Thorup har skrevet en vigtig, relevant og lærd bog om den politiske volds idehistorie. Der er al mulig god grund til at håbe og opfordre til, at denne bog opnår stor udbredelse og at den også læses af andre end forskere, navnlig beslutningstagere, der er optaget af 
at bekæmpe terrorisme, oprør, bandekriminalitet, pirateri og andre voldelige enterprizes. Selv har jeg allerede anført bogen i Danske Biblioteksmediers pjeces anbefalinger af litteratur om terrorisme.

Med god grund. For Mikkel Thorups studie af terrorisme som diskurs i moderniteten er original i ordets bedste forstand. Det er netop terrorismens og antiterrorismens diskurs, Thorup fremstiller og analyserer i sin bog. Den er ikke, som han gentagne gange understreger, endnu et bidrag til terrorismens historie, hvor der så traditionen tro tilføjes nye aktører, in casu pirater. Dens sigte er et andet og den tager afsæt i den politiske idehistorie og moderniteten. Det er der to grunde til.

For det første er det først med modernitetens indtræden, her regnet fra den franske revolution, at begrebet terrorisme vinder indpas som et politisk begreb. Terror har været kendt siden tidernes morgen til at beskrive frygt og som et instrument i magthavernes hænder til gennem frygt at forsvare deres magt og den etablerede orden. Terror var som sådan ikke et særligt politisk ladet begreb, men et middel i magthavernes hænder og midlet blev kun brugt defensivt eller reaktivt til at forsvare en given orden. Med den franske revolution bliver betydningen af terror imidlertid politiseret og forandret til et middel, der kan bruges kreativt, offensivt eller - om man vil bruge PET sprog - proaktivt. Terror bliver altså et middel, der bruges til at skabe en ny orden. Det er i den proces, at begrebet terrorisme vinder indpas i det politiske sprog, nemlig som vold i det godes tjeneste eller som vold, der ganske vist ses som illegal og illegitim, men som opnår legitimitet ved at stå i helhedens tjeneste i form af skabelsen af det gode samfund eller som f.eks. al-Qaida vil udtrykke det: det retfærdige samfund. Den, der bruger terror som middel i dette perspektiv, er en terrorist og alle "terroristers moder" er således en mand, nemlig Robespierre. Herefter bliver begrebet terrorisme til en slagmark, hvor der kæmpes om, hvem der bedst kan legitimere brug af vold og Thorup viser i sin bog, at det er den moderne stat, der vinder det slag: Statens voldsmonopol er legitimt og dem, der udfordrer er enten andre stater, det er krigens domæne, eller terrorister og det er antiterrorismens domæne. Men tesen i bogen er, at argumentationsfigurerne er de samme hvad enten det er den legitime stat eller den illegitime terrorist, der udøver vold. Forskellen er, hvem der har magt og suverænitet til at definere modstanderen som terrorist. Under den franske revolution knyttes terror sammen med dyd (i helhedens tjeneste) og faktisk også utopi forstået som fremtidens samfund. 
For det andet fremelsker Thorup den tese, at i moderniteten er volden en skandale: volden kriminaliseres og kræver derfor altid en undskyldning og legitimerende forklaring, hvor den mest udbredte er, at volden udføres for at begrænse volden. Det er hensigten og fortjenesten i Thorups fremstilling at vise, at alle voldsudøvere i moderniteten er bundet til denne retoriske figur. Det gør forfatteren bogen igennem i form af en lang række detailstudier, der bringer os fra terroristernes begrundelse for vold, over staters monopolisering af vold og den politiske idehistories teorier om krig og fred, til pirateri og staters brug af pirater, diskussionen om begrebet fjende af menneskeheden og analyserne følges helt op til legitimeringen af krigen mod terrorisme og begrundelser for humanitær intervention og argumentationsfiguren kulminerer i en besk analyse af den kosmopolitiske humanistiske voldslegitimation.

Teoretisk er Mikkel Thorup inspireret af Reinhardt Koselleck, Giorgio Agamben og Carl Schmitt, men mest tydeligt af Schmitt, hvis kyniske anti-humanisme som en dunkel stemme dukker op i de ironiske bemærkninger, forfatteren ikke kan nære sig for at komme med, når f.eks. Cheneys, George Bushs eller Rumsfelts legitimeringer af krig mod terrorisme bliver for hykleriske. Dette synes at være en lille stilistisk svaghed i bogen, der på den ene side fremstår lærd, køligt beskrivende, begavet analyserende, men på den anden side brydes af ølstuens brovtende ironiske udfald. Ikke ofte, ganske vist. Men dog alligevel.

Det er ikke blot en god bog. Det er også en udfordrende bog. Ikke kun på grund af den schmittske radikalitet i de gennemgående teser, men også fordi den kommer vidt omkring. I sin indledning angiver Thorup rigtignok en plan for bogens opbygning, men os, der har læst Thorups arbejder siden den fornemme Ph.D.- afhandling over terrorismestudierne til studierne i pirateri og antipirateriets diskurs genkender i hvert fald tre forskellige forskningsprojekter, der alle kredser om magtens evige gentagne forsøg på at sætte det afgrænsende skel mellem legitim og illegitim vold, men som udover det diskursive fællesskab dog for en mere nøgtern empirisk betragtning er ganske forskellige. De er i bogen bragt ind i en samlet fremstilling, hvilket naturligvis er helt i orden (tør man sige det?), men som alligevel udfordrer læseren, der måske (som undertegnede) interesser sig for terrorismestudier, men bestemt ikke for kosmopolitisk anlagte teorier om international politik. Men måske har netop vi godt af at få hele pakken?

For en lidt mere ydmyg empirisk orienteret læser, kan Thorups 
metode undertiden også være en udfordring. Metoden er velkendt: der fremsættes en tese og der hentes eksempler vidt og bredt til at bekræfte den. Det kommer der rigtig mange gode analyser ud af og man begaves med en overflod af gode citater, men nogle gange spørger man sig selv om de mange teksteksempler nu også er tilstrækkelige til at overbevise om tesens validitet. Men man kan jo egentlig også blot lade være med at stille sådanne bogholderagtige spørgsmål og blot nyde analyserne og det tekstuelle overflødighedshorn.

Hvorom alt er, har Mikkel Thorup beriget såvel terrorismestudierne som forskningen i den politiske volds idehistorie med en bog, der i meget lang tid vil være uomgængelig i forskningen i modernitet, terrorisme og staters evindelige legitimering af deres voldsmonopol.

MARTIN SKOVBJERG JENSEN

\section{Svag tænkning til stærke ledere}

Pia Lauritzen: Filosofi i ledelse - Vilkair for ledelsesteori og -praksis, Hans Reitzels Forlag, København, 2011, 240 sider, $275 \mathrm{kr}$.

Filosoffen Pia Lauritzen forsøger i et opråb at nå ledere og studerende, der hvor de er, når de leder. Dette gør hun i en bog, der tager udgangspunkt i en kritik af de filosofiske antagelser, som den ser som fundamentet for langt hovedparten af moderne ledelsesfilosofi. Disse antagelser udmærker sig ifølge Lauritzen ved, at de alle er blevet tilbagevist af den historiske tænkning, som med Hegel og Nietzsche indvarslede en ny metode for tænkningen.

Fordi Lauritzen mener, at hovedparten af moderne ledelsesfilosofi bygger på antagelser, som den historiske tænkning har tilbagevist, bliver historisk tænkning med Gianno Vattimo som den fremmeste repræsentant, udgangspunkt for hendes refleksioner omkring ledelse. Bogen kan derfor i bund og grund bedst sammenfattes som et forsøg på at vise, at Vattimos såkaldte "svage tænkning" udgør både en kritisk replik til, men også en konstruktiv udfordring for moderne lederes forestillinger om ledelse. Mere konkret skal Vattimo bruges til at vise, at en ledelsesfilosofis opgave slet ikke er at udvikle et ideelt begreb om ledelse, men i stedet at svække de strukturer som fastholder ledere i gængse tankemønstre, som kan tænkes at være uhensigtsmæssige. Ledelsesfilosofi skal ikke give svaret, men oplære ledere i filosofiens erfaring med at tænke.

Dette forsøg på at anvende den svage tænkning har to retninger. For det første skitseres en kritik af 